Khazanah: Jurnal Studi Islam dan Humaniora

ISSN: 0215-837X (p); 2460-7606 (e), Vol. 17 (2), 2019, pp. 297-318

DOI: $10.18592 /$ khazanah.v17i2.3209

Submit : 14/08/2019 Review : 30/08/2019 Publish : 31/12/2019

\title{
SYEKH NAWAWI AL-BANTANI DAN PEMIKIRANNYA DALAM PENGEMBANGAN PENDIDIKAN ISLAM
}

\author{
Ahmad Wahyu Hidayat \\ UIN Sunan Kalijaga Yogyakarta \\ ahmadwahyuhidayat95@gmail.com \\ Muhammad Iqbal Fasa \\ UIN Sunan Kalijaga Yogyakarta \\ muhammadiqbalfasa@ymail.com
}

\begin{abstract}
This article describes the meaning of education according to Sheikh Nawawi Al-Bantani by using library research and analytical study methods. Analytical studies used are analytical content and analytical descriptions of education according to Sheikh Nawawi Al-Bantani. The result of this study indicates that the purpose of education in Islam is a reflection of the function of humans to worship God by achieving His pleasure, striving to eradicate ignorance, and striving to perpetuate Islam with the light of knowledge. His thoughts about educators and students reveal that the personality factor of educators is more important than other factors, whereas, students themselves, they should always hold fast to noble morals in dealing with teachers, both in the teaching and learning process or in interacting with teachers in daily life.
\end{abstract}

Keywords: Islamic Education; Intellectual Journey; Islamic Scholar; Boarding School

\begin{abstract}
Abstrak: Penelitian ini menguraikan pendidikan menurut Syekh Nawawi Al-Bantani. Penelitian ini menggunakan penelitian kepustakaan dengan metode studi analitis. Studi analitis yang digunakan adalah analitis konten dan analitis deskripsi tentang pendidikan menurut Syekh Nawai Al-Bantani. Hasil penelitian ini menunjuk.kan bahwa tujuan pendidikan dalam Islam merupakan sebuah refleksi dari fungsi manusia untuk beribadah kepada Allah yaitu dengan mencapai keridhoanNya, berjïhad untuk memberantas kebodohan, berjihad untuk mengabadikan Islam dengan sinaran ilmu. Pemikiranny tentang pendidik dan peserta didik. mengungkapkan bahwa faktor kepribadian pendidik lebih penting daripada faktor yang lain, sedangkan dengan peserta didik sendiri hendaklah selalu berpegang teguh pada akblak mulia dalam menghadapi guru, baik dalam proses belajar mengajar ataupun dalam berinteraksi dengan guru dalam kehidupan sehari-hari.
\end{abstract}

Kata kunci: Pendidikan Islam; Perjalanan Intelektual; Ulama; Pesantren

\section{Pendahuluan}

Indonesia adalah salah satu negara yang mayoritas penduduknya beragama Islam. Kondisi tersebut tidak lepas dari peran ulama-ulama terdahulu yang giat menyebarkan agama Islam. Di antara ulama-ulama tersebut ada satu sosok ulama yang luar biasa, yaitu Syekh Nawawi Al-Bantani yang merupakan sosok ulama multidimensional dengan latar belakang pendidikan pesantren. Nama beliau sudah sangat di kenal baik di kalangan akademisi maupun praktisi pendidikan Islam di seluruh 
penjuru dunia. Melalui karya-karya dan pemikirannya yang monumental, beliau telah memberikan pengaruh dalam berbagai bidang keilmuan meliputi bidang tafsir, tauhid, fiqh, tasawuf, sejarah Nabi serta bahasa dan retorika. ${ }^{1}$ Karya-karya beliau memberikan sumbangan yang sangat besar dalam kemajuan Islam di Indonesia, dan sampai sekarang, karya-karya Syekh Nawawi masih terus dikaji dan diajarkan sehingga memberikan pengetahuan tentang ajaran Islam yang menyejukkan.

Syekh Imam Nawawi Al-Bantani adalah ulama yang sangat terkenal, tidak hanya di Indonesia tapi juga di Makkah. Syekh Nawawi telah mensyarah beberapa kitab dalam bidang teologi atau ilmu tauhid karya ulama abl al-sunnah wa al-jama'ah dari mazhab empat, kecuali mazhab Hambali. Diantaranya kitab tijan al-Darariy, syarah dari kitab Risalah Ibrahim al-Bajuriy dan kitab Fathul al-Majid ulasan atas Durr al-Farid fi'Ilm al- Taubid karya Ahmad al-Nahrawi, guru Syaikh Nawawi.

Usaha pensyarahan ini menunjukan bahwa Syekh Nawawi sudah mengadakan pendekatan pada faham-faham ulama dari berbagai mazhab, kecuali dari mazhab Hambali. Walaupun mazhab-mazhab fiqih ini masih dalam satu alur dalam aspek teologis, yaitu ahl al-sunnah wa al-jamaa'ah, namun tentunya ada varian perbedaan diantara mereka. Hanya sampai di mana pengaruh faham-faham kalam tersebut terhadap kitab-kitab karangannya, menurut penulis, kitab-kitab yang dibuat oleh Syekh Nawawi al-Bantani mudah dipahami oleh orang-orang yang mempelajarinya, dikalangan santri, siswa, dan mahasiswa (semua kalangan) karena pembahasannya disesuaikan dengan kebutuhan masyarakat dan pelajar, dan meskipun kitab-kitabnya ditulis dengan bahasa Arab tidak menjadi penghalang bagi berbagai kalangan tersebut untuk memahaminya. ${ }^{2}$

Dengan demikian, rumusan pendidikan selalu berawal dari konsep tentang manusia dalam berbagai dimensinya, yang merupakan refleksi dari pemikiranpemikiran dinamis dan kreatif. Tanpa berorientasi kepada manusia sebagai acuan dasar, maka rumusan-rumusan pendidikan Islam akan mandeg dan gamang sehingga sulit menghadapi dan mengantisipasi problem-problem pendidikan.

Ilyas mengemukakan bahwa pada beberapa keluarga dengan tingkat pendidikan dan kesadaran akan bahaya media internet yang dangkal tidak terlalu mempersoalkan dan memberikan aturan dan batasan yang cukup kepada anak untuk mengakses saluran-saluran tersebut yang kemudian berdampak pada degradasi akhlak pada anak, padahal keluarga dalam Islam merupakan unsur yang berperan penting dalam pendidikan dan pembinaan akhlak. ${ }^{3}$

Oleh karena itu pada masa seperti sekarang ini kita perlu mengetahui, mempelajari,serta mengambil hikmah dan pelajaran dari kisah dan pemikiran tokoh dalam dunia pendidikan Islam. Dari uraian diatas penulis akan mengurai tentang Pemikiran Pendidikan Syekh Nawawi al-Bantani.

\footnotetext{
${ }^{1}$ Bashori -, "Pemikiran Pendidikan Syekh Nawawi Al-Bantani," Hikmah: Jurnal Pendidikan Islam 6, no. 1 (June 1, 2017): 38.

${ }^{2}$ Machasin, Islam Teologi Aplikatif (Pustaka Alief, 2003), 27.

${ }^{3}$ M. Azizzullah Ilyas, "Ajaran Syeikh Nawawi al-Bantani Tentang Pendidikan Akhlak Anak," AR-RIAYAH: Jurnal Pendidikan Dasar 2, no. 2 (January 22, 2019): 113-26, https://doi.org/10.29240/jpd.v2i2.659. 


\section{Metode}

Penelitian ini merupakan penelitian kepustakaan. Penelitian kepustakaan adalah pengungkapan argumentatif dari sumber data dalam bentuk studi. ${ }^{4}$ Sumber data penelitian ini adalah buku-buku yang berkaitan dengan pendidikan menurut Syekh Nawawi al-Bantani. Sumber lain adalah temuan penelitian, hasil diskusi, seminar, dan sebagainya. Bahan pustaka kemudian dibahas dan dianalisis secara kritis dan mendalam untuk mendukung proposisi dan gagasan yang ada dari berbagai referensi.

Pengumpulan data dalam penelitian ini menggunakan teknik dokumentasi, pencarian data atau teori yang relevan dengan pertanyaan penelitian, yaitu, bagaimana pendidikan menurut Syekh Nawawi al-Bantani dalam bentuk catatan, buku, laporan temuan penelitian, artikel ilmiah, jurnal dan sebagainya. Setelah data terkumpul maka data dianalisis. Metode analisis yang digunakan adalah analisis konten dan analisis deskriptif.

\section{Pembahasan}

\section{Biografi Syekh Nawawi Al-Bantani}

Syekh Nawawi, atau nama lengkapnya Abu Abdul Mut'hi Muhammad Nawawi ibn Umar al-Tanari al-Bantani al-Jawi merupakan seorang ulama yang tersohor dikalangan para santri dan ulama Indonesia dengan sebutan Syekh Nawawi Al-Bantani. Beliau lahir di kampung Tanara, kecamatan Tirtayasa, Kabupaten Serang, Keresidenan Banten pada tahun $1813 \mathrm{M} / 1815 \mathrm{M}^{5}$

Secara silsilah Nawawi merupakan keturunan ke-12 dari Maulana Syarif Hidayatullah (Sunan Gunung Jati Cirebon), yaitu keturunan dari putra Maulana Hasanuddin (Sultan Banten 1) yang bernama Sunyararas (Tajul 'Arsy). ${ }^{6}$ Nasabnya bersambung dengan Nabi Muhammad SAW melalui ayahnya K.H. Umar dan ibunya Zubaidah.

Untuk jelasnya silsilah Syekh Nawawi dari garis ayahnya sebagai berikut: Syekh Nawawi bin Kyai Umar bin Kyai Arabi bin Kyai Ali bin Kyai Jamad bin Ki Janta bin ki Masbugil bin ki Masqun bin Ki Masnun bin Ki maswi bin Ki Tajul Arusy tanara bin Maulana Hasanuddin Banten bin Maulana Syarif Hidayatullah Cirebon bin Raja Amatudin Abdullah bin Ali Nuruddin bin Maulana Jamaluddin Akbar Husain bin Imam Sayyid Ahmad Syah Jalal bin Abdullah Adzmah Khan bin Amir Abdullah Malik bin Sayyid Alwi bin Sayyid MuhammadShahib Mirbath bin Sayyid Ali Khali' Qasim bin Sayyid Alwi bin Imam Ubaidillah bin Imam Ahmad Muhajir Ilallahi bin Imam Isa AnNaqib bin Imam Muhammad Naqib bin Imam Ali Aridhi bin Imam Ja'far Ash-Shaddiq bin Imam Muhammad Al-Baqir bin Imam Ali Zainal Abidin bin Sayyiduna Husain bin

${ }^{4}$ Nana Syaodih Sukmadinata, Metode Penelitian Pendidikan (Bandung: Program Pascasarjana Universitas Pendidikan Indonesia dengan PT Remaja Rosdakarya, 2005), 15.

${ }^{5} \mathrm{H}$. Abuddin Nata, Pembaruan Pendidikan Islam di Indonesia (Jakarta: Prenada Media, 2019), 290.

'Salman Iskandar, 55 Tokoh Muslim Indonesia paling berpengaruh (Tinta Medina, 2011), 63.

Khazanah, Vol. 17 (2), 2019 
Sayyidatuna Fathimah Zahra binti Muhammad Rasulullah SAW dan Silsilah dari garis ibunya adalah Syekh Nawawi bin Nyi Zubaidah binti Muhammad Singaraja. ${ }^{7}$

\section{Perjalanan Intelektual Syekh Nawawi al-bantani}

Sejak kecil Syekh Nawawi telah diarahkan ayahnya, K.H. Umar bin Arabi yang merupakan seorang pejabat penghulu yang memimpin masjid untuk menjadi seorang ulama. Kecerdasan beliau sudah terlihat sejak kecil yang mana pada usia 5 tahun Syekh Nawawi dengan mudahnya menerima pelajaran yang telah di berikan ayahnya. Melihat potensi yang ada pada diri anaknya, K.H Umar menyerahkan putranya kepada K.H Sahal yang merupakan ulama terkenal di Banten. Setelah belajar dengan K.H Sahal, Nawawi melanjutkan pendidikannya kepada K.H. Yusuf yang merupakan ulama besar Purwakarta. ${ }^{8}$

Suasana religius dalam keluarganya juga turut memberi kontribusi pada tradisi pendidikan tinggi Nawawi. Dia memperoleh pelajaran pertama dari ayahnya Umar bin Arabi. Ibunya Zubaidah, penduduk Tanara, juga dilaporkan sebagai seorang yang religius, perhatian, dan penuh cinta kasih. Semasa kecil, Nawawi pernah berpamitan dengan ibu kandungnya untuk pergi mengaji menuntut ilmu, ibunya melepas sang anak yang dikasihinya itu dengan pesan "aku do'akan dan kurestui kepergianmu mengaji dengan suatu syarat: Jangan pulang sebelum pohon kelapa yang sengaja kutanam ini berbuah". Ibunya memang berharap agar anaknya menuntut ilmu secara sungguhsungguh dan tidak cepat puas. Nawâwî memiliki tujuh saudara, yaitu: Nawâwî, Ahmad Shihâbûddîn, Said, Tamin, Abdullah, Syakilah, dan Syahriyah. ${ }^{9}$

Kecintaan Syekh Nawawi terhadap ilmu Agama membuat dirinya bersemangat untuk selalu mempelajari berbagai macam jenis ilmu agama. Imam Nawawi kelihatanya sangat terpengaruh dengan pernyataan Imam Safi'i dalam mendorong pencarian ilmu kepada murid-muridnya. "Tidaklah layak bagi seseorang yang berakal dan berilmu beristirahat dalam mencari ilmu, tinggalkan negerimu dan berkelanalah, kelak engkau akan menemukan pengganti orang yang kau tinggalkan, bersusah payahlah, karena sesungguhnya ketinggian derajat kehidupan hanya bisa dicapai dengan kesusahpayahan". ${ }^{10}$

Pernyataan tersebut memacu dan mendorong Syekh Nawawi Al-Bantani untuk menggali, mencari, dan memperdalam ilmu agamanya pada usia 15 tahun, dimana pada usia tersebut Syekh Nawawi bersama kedua saudaranya pergi ke Makkah untuk menunaikan ibadah Haji. Setelah musim haji usai Ia tidak langsung pulang ke Indonesia melainkan tinggal di Makkah untuk memperdalam ilmu Agamanya. ${ }^{11}$ Kesempatan ini

${ }^{7}$ Abdul Aziz Masyhuri dan Zainal Arifin Thoha, 99 Kiai Kharismatik Indonesia: Riwayat, Perjuangan, dan Doa (Kutub, 2008), 100.

${ }^{8}$ Masyhuri dan Thoha, 100.

9Shalahuddin Hamid dan Iskandar Ahza, Seratus Tokoh Islam yang Paling Berpengarub di Indonesia (Jakarta: Intimedia, 2003), 87.

${ }^{10}$ Suwito and Fauzan, Sejarah Pemikiran Para Tokob Pendidikan (Bandung: Angkasa Bandung, 2003), 87.

${ }^{11}$ Iskandar, 55 Tokoh Muslim Indonesia Paling Berpengaruh, 64. 
digunakannya untuk belajar Ilmu kalam, bahasa dan sastra Arab, llmu hadits, tafsir dan terutama belajar ilmu fiqh. ${ }^{12}$

Melihat kondisi sosial yang tidak nyaman bagi beliau dan karena keenggananya bekerjasama dengan pemerintah kolonial, lantas beliau bertekad untuk kembali ke Hijaz. Entah berapa lama beliau berada di Banten, beberapa sumber menyebutkan waktu yang berbeda, ada yang mengatakan beberapa bulan saja dan ada yang mengatakan tiga tahun di banten, baru kembalik Makkah. Dari sinilah kiprah internasional Syeikh Nawawi al-Bantani dimulai, bersama santri asal Jawa yang lain, beliau kembali menuntut ilmu dengan menghadiri majlis-majlis ulama Haramain, tidak puas di situ, beliau juga pergi ke Mesir dan Syam untuk menimba ilmu di sana, dari Mesir, beliau tidak kembali ke tanah air, tetapi kembali ke Hijaz dan menetap di sana. ${ }^{13}$

Dorongan serta ketekunan yang kuat menyebabkan Nawawi bertahan di Makkah untuk menimba ilmu kepada ulama-ulama besar kelahiran Indonesia dan negeri lainnya seperti Makkah, Hejaz, dan daerah-daerah sekitar Makkah serta beliau sempat belajar hingga ke Mesir. ${ }^{14}$ Pertama kali beliau belajar di Masjidil Haram Makkah yang ketika itu merupakan satu-satunya pendidikan Islam tertinggi di Makkah. Ditempat ini beliau belajar kepada Syekh Sayyid Akhmad Nakhrawi, Syekh Sayyid Ahmad Dimyati, dan Syekh Ahmad Zaini Dahlan dan setelah itu beliau belajar di Madinah pada Syekh Khatib Al-Hambali. ${ }^{15}$ Banyak hal yang ia pelajari dari gurugurunya tersebut, mulai dari ushuluddin, fiqh, balaghah, sampai dengan mantiq.

Nawawi terkenal sebagai salah seorang ulama besar di kalangan umat Islam internasional. Ia dikenal melalui karya-karya tulisnya dan memeperoleh gelar kehormatan dari Arab Saudi, Mesir, dan Suriah diberikan kepadanya. Walaupun begitu, kehidupan Nawawi penuh dengan kesederhanaan. Kesederhanaannya sangat mengesankan sehingga seakan-akan bukan seorang Syekh Guru Besar. Mamat S. Burhanuddin, dalam bukunya mengatakan: "Dengan sinis Snouck bercerita bahwa penampilan Nawawi yang tidak mementingkan penampilan, sehingga sampai-sampai jika fiqh Islam tidak mewajibkan kebersihan, dia pastilah menjadi orang yang kotor sekali". Sikap sederhananya bukan berarti meninggalkan urusan dunia, ia pernah mencoba aktif menjadi syekh haji (semacam biro perjalanan haji) sebagaimana dijalankan oleh adiknya, Tamim. Namun segera ia tinggalkan karena ia merasa bahwa dirinya bukan seorang tipe berbakat dalam mencari uang dan kehidupan mewah. Para muridnya pun lebih menyarankan demikian karena ia tidak cocok untuk itu. Selain itu Nawâwî juga membiarkan salah satu dari istrinya berprofesi sebagai pedagang. Semua kebutuhan rumah seperti makan untuk tamu dipenuhi oleh istrinya. ${ }^{16}$

${ }^{12}$ Maragustam, "Pemikiran Syaikh Nawawi Al-Banjari tentang Manusia dan Implikasi dalam Pendidikan Islam," Jurnal Kependidikan Islam I, no. 1 (July 1, 2003): 15.

${ }^{13}$ Rofik Maftuh, "Inklusifitas Pemikiran Syaikh Nawawi Al-Bantani," MAGHZA: Jurnal Ilmu Al-Qur'an Dan Tafsir 3, no. 1 (28 Juni, 2018): 124, https://doi.org/10.24090/maghza.v3i1.1960.

${ }^{14}$ Maftuh, 123.

${ }^{15}$ Suwito and Fauzan, Sejarah Pemikiran Para Tokoh Pendidikan, 290.

${ }^{16}$ Mamat S. Burhanuddin, Hermeneutika al-Qur'an Ala Pesantren: Analisis terhadap Tafsir Marāh Labīd Karya K.H. Nawawi Banten (Yogyakarta: UII Press, 2006), 24.

Khazanah, Vol. 17 (2), 2019 
Ulama yang cukup mewarnai prinsip keilmuan dan jalan pikiran Syekh Nawawi Al-Bantani adalah Syekh Sayyid Akhmad Nakhrawi dan Syekh Sayyid Ahmad Dimyathi, sebab dua ulama inilah yang mula-mula membimbing Nawawi dalam berbagai disiplin ilmu, membentuk karakternya dengan sikap positif didalam menghadapi goncangan psikologis yang ada dan mengajarkan untuk selalu memegang nilai-nilai Agama dan memantapkan prinsip Aqidah.

Tiga tahun lamanya, Nawawi menggali ilmu dari ulama-ulama Makkah, setelah merasa bekal ilmunya cukup, ia kembali ke tanah kelahirannya untuk memulai mengamalkan dan mengajarkan ilmu yang dimilikinya kepada umat yang sangat mengharapkan kehadirannya. Akan tetapi karena kondisi tanah air ketika itu masih berada dibawah penjajahan Belanda, dan setiap gerak-gerik ulama diawasi,termasuk kegiatan Syekh Nawawi-Al-Bantani, beliau kembali kembali ke Makkah dan tinggal di perkampungan Syi'ib. ${ }^{17}$

Kecerdasan dan ketekunan menghantarkannya menjadi salah satu murid yang terpandang di Masjidil Haram. Ketika Syekh Ahmad Khatib Sambas uzhur menjadi imam Masjid, ia ditunjuk untuk menggantikannya. Sejak itulah ia menjadi Imam Masjidil Haram dengan panggilan Syekh Nawawi Al- Bantani Al-Jawi. selain menjadi imam ia juga mengajar dan menyelenggarakan diskusi ilmiah secara balaqab bagi muridmuridnya yang datang dari berbagai belahan dunia yang berkisar pada tahun 1860-1870 yang merupakan tahun dimana ia sudah secara aktif menulis berbagai kitab.

Laporan C. Snouck Hurgonje, seorang orientalis pernah mengunjungi Makkah pada tahun 1884-1885 menyebutkan sejak pukul 07.30-12.00, Syekh Nawawi memberikan tiga perkuliahan sesuai dengan kebutuhan jumlah muridnya, sebagian muridnya berasal dari Indonesia, seperti K.H Khalil (Madura), K.H. Hasyim Asy'ari (Jawa Timur), K.H. Raden Asnawi (Jawa Tengah), K.H. Asy'ari (Bawean), K.H. Asnawi (Caringin Labuan Banten), K.H. Tubagus Bakri ( Sempur Purwakarta), serta K.H Arsyad Thawil dari Banten. Mereka inilah yang kemudian menjadi ulama-ulama terkenal. $^{18}$

C. Snouck Hurgronje sewaktu mengunjungi Makkah selama enam bulan pada tahun 1884/1885, sempat berdialog langsung dengan Syekh Nawawi. Kemudian laporan itu ia bukukan dengan judul Meca, in the Latter Part Of The 19th Century, Snouck mengatakan bahwa Syekh Nawawi setiap pagi, antara jam 7.30 dan 12.00 memberi tiga perkuliahan yangdirencanakan sesuai dengan kebutuhan jumlah murid-muridnya. Dia menerima murid baru,sejak tingkat permulaan tata bahasa Arab, disamping murid yang sudah cukup pintar dan yang mengajar sendiri di tempat mereka. Golongan ini juga mengambil alih sebagian tugasnya dibidang pendidikan dasar, seperti juga beberapa orang yang hidup di rumahnya (antara lain adiknya sendiri Abdullah, umur 16 tahun yang sepanjang hidupnya dididik oleh kakaknya sendiri). Syekh Nawawi juga pernah 2007), 157.

${ }^{17}$ Sudirman Tebba, Mengenalkan Wajah Islam yang Ramab: Sufi-Sufi Jawa (Ciputat: Pustaka Irvan,

${ }^{18}$ Toni Pransiska, "Pendidikan Islam Transformatif Syaikh Nawawi Al-Bantani: Upaya Mewujudkan Generasi Religius-Saintifik," JURNAL ILMLAH DIDAKTIKA: Media Ilmiah Pendidikan Dan Pengajaran 18, no. 2 (February 1, 2018): 172-188, https://doi.org/10.22373/jid.v18i2.3241. 
berdialog langsung dengan Syekh Muhammad Abduh dan beberapa kali memberikan ceramah di Universitas Al-Azhar. ${ }^{19}$

\section{Karya-karya Syekh Nawawi al-bantani}

Syekh Nawawi juga sangat giat dalam menulis buku, ia termasuk penulis yang produktif dalam melahirkan kitab-kitab mengenai berbagai persoalan agama, paling tidak ada 34 karyanya tercatat dalam Dictionary Of Arabic Prientea Books karya Yusuf. ${ }^{20}$ Beberapa kalangan malah menyebut karyanya-karyanya mencapai lebih dari 100 judul, meliputi berbagai disiplin ilmu, seperti tauhid, ilmu kalam, sejarah, syari'ah, tafsir dan lainya. Diantara buku yang ditulisnya dan mu'tabar adalah tafsir Marah Labid, Atsimar Al-Yaniah fi Ar-Riyadah Al-Badiah, Nuraz̆ Sullam, Al-Futubat Al-Madaniyah, Tafsir AlMunir,Tangih Al-Qoul, Fath majid, Sullam Munajah, Nihayah Zein, Salalim Al-Fudhala, Bidayah Al-Hidayah, Al-Ibriz, Al-Dani, Bugyah Al-Awwam, Futhus Samad, dan Al-Aqdhu Tsamin. $^{21}$

Uraian lebih jelas karya-karya syekh nawawi oleh M.Th.Moutsma dan A.J.Wensinch dkk,serta Harun di klasifikasikan kedalam nomor-nomor berikut: ${ }^{22}$

1. Bidang Ilmu Kalam (Teologi Islam), diantaranya: Kitab Fath Al- Majid (1298 H), Tijan Al-darari $(1301 \mathrm{H})$, Kasyifah Al-Saja $(1292 \mathrm{H})$, Al-Nabjah Al-Jadidab $(1303 \mathrm{H})$, Zari'ah al-Yaqin 'ala Umm al-Barahin $(1317 \mathrm{H})$, Al-Risalah al-jami'ah Bain Usul al-din wa al-Fiqh wa al-Tasawuf (1292 H), Al-Simar al-Yani'ah (1299 H), Hilyab al-Sibyan 'ala Fath Al-Rahman (Tanpa Tahun) dan Nur-al-Zulam (1329 H).

2. Bidang Fiqh (hukum Islam), diantaranya: Al-Tausyeb $(1314 \mathrm{H})$,Sulam al-Munajat (1297 H), Nihayah al-Zain (1297 H), Mirqah Al-Su'ud Al-Tasdiq (1292 H), Suluk AlJadah $(1300 \mathrm{H})$, Al-Aqd Al-Samin $(1300 \mathrm{H})$, Fath Al-Mujib (1276 H), 'Uqud al-Lujaen fi Bayan Huquq Al-Zaujaen (1297 H), Qutul Habibi Al-Garib (1301 H), dan Kasyifah Al-saja $(1292 \mathrm{H})$. Karya-karya tersebut merujuk Madzhab Syafi'i dimana beliau sebagai pengikutnya.

3. Bidang Akhlak/Tasawuf, perilaku sufinya nampak dalam kezuhudan dan ketawaduanyya. Tarekat yang diikutinya adalah tarekat Qadiriah, karena beliau sangat erat hubunganya dengan Kyai Abdul Karim bin Bukhori bin Ali yang dikenal sebagai tokoh tarekat Al-Qadiriah di Makkah dan sama-sama berasal dari banten. Tulisannya di bidang ini antara lain: Qami' Al-Tugyan 'ala Manzumah Syub al-iman (1296 H), Salailim al-Fudala (1315 H), Misbah Al-Zulm 'ala Manbaj al-Atam fi Tawbib

\footnotetext{
${ }^{19}$ Snouck Hurgronje, Mekek in the Latter Part of the 19th Century: Daily Life, Customs and Learning. The Moslims of the East-Indian Archipelago. (Leiden: BRILL, 2006), 269. 30.

${ }^{20}$ Mihmidaty Ya'cub, Model Pendidikan Tasawuf pada Tariqah Shadhiliyah (Pustaka Media, 2018),

${ }^{21}$ Muhammad Ulul Fahmi, Ulama Besar Indonesia: Biografi dan Karyanya : Syekh Nawawi al-Bantani, Syekh Kholil Bangkalan, Syekh Mabfudh at-Turmusi, Syekh Yasin Padang, Syekh Ihsan Jampes, Syekh Muslih Mranggen, dan Lainnya (Kendal: Kerja sama Pondok Pesantren Al-Itqon dengan Pustaka Amanah Kendal, 2008), 11-12.

${ }^{22}$ Maragustam, "Pemikiran Syaikh Nawawi Al-Banjari Tentang Manusia dan Implikasi dalam Pendidikan Islam," 7.
}

Khazanah, Vol. 17 (2), 2019 
al-Hukm (1314 H), Maraqi al-Ubudiyah (1298 H), dan Syarh ala Manzumah a Al-Syekh Muhammad Al-Dimyati fi al-Tawassul bi Asma' Allah Al-Husna (1302 H).

4. Bidang tarikh kelahiran/kehidupan Nabi Muhammad SAW. Seperti: Al-Ibrir AdDani (1292 H), Madarij Al-Su'ud ila Iktisa'il Burud (1296 H), dan Fath Samad (1292 $\mathrm{H})$.

5. Bidang bahasa dan kesusateraan Arab. Misalnya: Fath Gafir Al-Khotibiyah 'ala Alkawakib Al-Jaliyah Fi Nazm Al-Jurimiyah (1298 H), Al Fusush Al-Yaqutiyah (1299 H), Kasyf Al-Marutiyah (1292 H), dan Luba Al-Bayan (1301 H).

6. Bidang Tafsir-Hadits. Beliau menulis tafsir Murah atau Al-Munir $(1305 \mathrm{H})$ yang terdiri dari dua jilid Tanqih al-Qaul (tanpa tahun) dalam bidang hadis. ${ }^{23}$

Kitab-kitab Syekh Nawawi Al-Bantani banyak di terbitkan di Mesir. Selanjutnya, kitab-kitabnya itu menjadi bagian dari kurikulum pendidikan agama di seluruh pesantren di Indonesia, bahkan Malaysia, Filifina, Thailand, dan juga Timur Tengah.

Setelah karyanya banyak masuk di Indonesia, wacana keislaman yang dikembangkan di pesantren mulai berkembang. Sejak 1888, kurikulum pesantren mulai ada perubahan yang mencolok. Jika sebelumnya tidak ditemukan sumber referensi dibidang tafsir, ushul fiqh, dan hadits, sejak saat itu bidang keilmuan tersebut mulai dikaji. Karya-karya Syekh Nawawi memang mendominasi kurikulum pesantren sampai tahun 1990 yang tidak terlepas dari jasa K.H. Hasyim Asy'ari, yang merupakan salah seorang murid Syekh Nawawi yang berasal dari Jombang.

Syekh nawawi Al-Bantani wafat dalam Usia 84 Tahun di Syeib 'Ali, sebuah kawasan dipinggiran kota Makkah, pada 25 Syawal 1314 H/1897 M di kediamannya di Shi'ib Ali Makkah. Jenazahnya dimakamkan dipemakaman Ma'la Makkah, berdekatan dengan makan Ibnu Hajar dan Siti Asma binti Abu Bakar Ash-Shiddiq. Dia wafat pada saat sedang menyusun sebuah buku yang menguraikan Minhaj ath-Thalibin-nya Imam Yahya bin Syaraf bin Mura bin Hasan bin Husain bin Muhammad bin Jam'ah Hujam An-Nawawi. ${ }^{24}$

\section{Ide-ide Pendidikan Syekh Nawawi Al-Bantani}

Pada prinsipnya para ahli sependapat dalam hal membangun ide-ide dasar pendidikan Islam yaitu, ontologi, pandangan Islam tentang jagad raya, manusia, kehidupan dunia akhirat dan lingkungan masyarakat muslim, epistimologi yakni pandangan Islam tentang pengetahuan, dan aksiologi yakni pandangan Islam tentang nilai-nilai akhlak.

${ }^{23}$ Dalam bidang tafsir Syekh Nawawi al-Bantani dikenal sebagai orang non-Arab yang mampu menulis tafsir dalam bahasa Arab yang sangat indah. Jika dibandingkan dengan Muhammad Abduh (w.1905) Nawawi mampu menampikan model a new classical tradisi tafsir yang memberikan perhatian serius terhadap karya tafsir abad pertengahan seperti Ibnu Umar Kasir al-Quraisy sekaligus menunjukkan dimensi-dimensi aktual kekinian. Sedangkan Abduh banyak dipengaruhi oleh pemikiran Muktazilah. Abdurrahman Mas'ud, Dari Haramaian Ke Nusantara; Jejak Intelektual dan Arsitek Pesantren (Jakarta: Kencana, 2006), 129.

${ }^{24}$ Tebba, Mengenalkan wajah Islam yang ramah, 155. 
Dalam hal ini kita akan membahas mengenai ide-ide pemikiran pendidikan Syekh Nawawi Al-Bantani, diantaranya:

\section{Eksistensi Alam Semesta}

Menurut Syekh Nawawi-Albantani, Tuhan adalah pencipta langit dan bumi dan apa saja diantara keduanya dengan tujuan (hikmah) tertentu baik tujuan keagamaan maupun keduniaan, agar para ilmuan memikirkan, mengetahui dan mengambil-buktibukti dari padanya. ${ }^{25}$ Artinya, alam sebagai ciptaan-Nya telah dirancang dengan tujuantujuan tertentu, agar manusia mengakui eksistensi Tuhan, mencari rezki, ilmu dengan memanfaatkan hukum alam serta mencari kebahagiaan hidup dunia dan akhirat.

Bagi Syekh Nawawi, disamping ukuran-ukuran tertentu dari setiap jenis alam ini, sifat alam atau Sunatullah juga berjalan atas dasar hukum kausal. Seperti halnya hakekat reproduksi dalam kehiran anak tidak dapat berhasil tanpa perantaraan bapak.demikian pula hakikat terjadinya sesuatu atau terjadinya reproduksi secara maknawi tidak akan berhasil tanpa adanya pendidik, penunjuk, atau instruktur. ${ }^{26}$ Dengan kata lain, mustahil ada kelahiran atau timbulnya sesuatu secara maknawi tanpa adanya penunjuk atau pendidik atau instruktur.

Syekh Nawawi juga mengatakan, alam ini diciptakan dengan penuh keharmonisan dan keteraturan, penuh kepastian (takdir) dan tetap, bahkan Tuhan pun tidak akan mengubah hukum ketetapan (sunatullah) yang diciptakan-Nya. Dengan adanya kepastian dan keteraturan itu maka hukum alam itu berulang dan objektif. ${ }^{27}$

Dengan demikian hakikat alam semesta menurut Syekh Nawawi dapat diringkas menjadi 6 prinsip, yaitu pertama, adanya alam semesta diciptakan Allah dengan kepastian (ukuran-ukuran tertentu). Kedua, hukum alam (sunatullah) itu tidak pernah berubah atau berjalan terus menerus. Ketiga, sifat sunatullah alam ini ialah adanya keterulangan. Keempat, sunatullah sifatnya objektif, kelima, bahwa penciptaan alam ini mempunyai hikmah atau tujuan yakni agar dapat dipelajari dan diteliti sehingga bermanfaat dan berguna bagi kehidupan keagamaan dan keduniaan. Keenam, alam semesta ini berjalan atas dasar hukum kausal.

\section{Eksistensi Manusia}

Tuhan menciptakan manusia yang terdiri dari unsur roh dan jasad dengan rumit dan penuh misteri sebanding dengan jati dirinya yang unik, misterius dan tak terduga serta sifat-sifat kompleksnya. Roh dan jasad dua unsur yang tidak bisa dipisah satu dengan yang lainnya; keduanya merupakan satu kesatuan yang saling menyempurnakan. Menurut Syekh Nawawi sewaktu menafsirkan QS.Al-Hijr (15):2829 dan QS.Al-Rahman (55):14, bahwa Allah menciptakan Adam AS dari salsal yakni tanah liat kering tanpa dimasak yang bersuara ketika diukir, yang berasal dari tanah lumpur hitam yang basah dan diberi bentuk dengan serupa Adam. ${ }^{28}$

\footnotetext{
${ }^{25}$ Maragustam, "Pemikiran Syaikh Nawawi Al-Banjari Tentang Manusia Dan Implikasi Dalam Pendidikan Islam," 7.

${ }^{26}$ Maragustam, 8.

${ }^{27}$ Maragustam, 9.

${ }^{28}$ Maragustam, 10.

Khazanah, Vol. 17 (2), 2019 
Dengan kata lain dapat dijelaskan bahwa Allah satu-satunya pencipta manusia. Penciptaan Adam adalah langsung dari ekstrak tanah, sedangkan penciptan manusia pasca Adam berasal dari ekstakta tanah secara tidak langsung yakni melalui reproduksi biologis dari pasangan suami istri dan bahan penciptaannya berasal dari ekstrata tanah dan roh. Di samping manusia diberi roh, manusia juga diberi potensi-potensi yang mengagumkan dan penuh misteri.

\section{Potensi-Potensi Manusia}

Syekh Nawawi berpandangan bahwa manusia diciptakan dalam bentuk seimbang dan sempurna. Secara fisik manusia dapat berdiri tegak sempurna dan seimbang serta dilengkapi dengan akal, kemampuan, memahami, memperoleh imu dan memiliki budi pekerti. Allah menciptakan manusia terdiri dari berbagai unsur yakni dapat bertutur, mendengar, melihat dan bernalar.setiap unsur menyimpan berbagai keajaiban yang tidak dapat dijangkau oleh orang-orang yang mensifatinya. ${ }^{29}$ Jadi manusia diberi kemampuan baik yang bersifat biologis maupun yang bersifat psikologis. Penjelasan Syekh Nawawi tersebut pada prinsipnya telah menggambarkan potensi-potensi manusia yakni potensi fisik dan psikis.

Bergerak dari pendapat Syekh Nawawi maka dari sinilah potensi- potensi tersebut harus dikembangkan karena Potensi-potensi fisiologis dan psikologis manusia tidaklah cukup jika hanya mengandalkan perjanjian primordial dengan Tuhan. Potensipotensi itu harus dikembangkan melalui pedidikan. Karena tanpa ilmu maka manusia tidak akan mampu mengemban amanah khalifah dan melaksanakan ubbudiyah yang merupakan tanggung jawab manusia untuk menunaikannya.

\section{Prinsip-Prinsip Aktivitas Pendidikan Islam}

Hakikat pendidikan dan pengajaran dalam Islam menurut Syekh Nawawi mencakup ta'lim, tarbiyah dan $t a^{\prime} d i b$. Pendidikan mencakup transfer of knowledge, transfer of value, transfer of methodology dan transformasi. Pendidikan mencakup jasmani (praktik/amal), intelektual, mental/spiritual dan berjalan sepanjang hidup dan integral.

Sifat-sifat pendidikan yang dikemukakan oleh para ahli pendidikan Islam termasuk Syekh Nawawi sangat ketat. Hal ini karena peranan guru dalam Islam tidak sekedar ahli ilmu, nilai dan metode, tetapi juga transformasi (membentuk kepribadian peserta didik). Di samping itu diyakini bahwa para pendidik menempati posisi ulama sebagai pewaris para nabi, sehingga pendidik harus dapat menjadi teladan bagi peserta didiknya.

\section{Tujuan pendidikan}

Menurut Syekh Nawawi tujuan memperoleh ilmu atau tujuan pendidikan ialah mardatillah dan memperoleh kehidupan ukhrawiyah, memberantas kebodohan, memajukan Islam, melestarikan Islam dengan kaidah-kaidah ilmu serta sebagai perwujudan dari rasa syukur karena diberi akal dan tubuh yang sehat. Kewajiban

\footnotetext{
${ }^{29}$ Nurul Faiqoh, "Pemikiran Pendidikan Islam Syekh Nawawi Al-Bantani dan Implikasinya terhadap Pendidikan Modern," At-Tajdid: Jurnal Ilmu Tarbiyah 4, no. 1 (January 1, 2015): 1-12. 
bersyukur mencakup aspek keilmuan (ranah kognitif), aspek rasa senang (ranah afektif), dan menggunakan nikmat Tuhan sesuai dengan permintaan pemberi nikmat yakni Allah (ranah psikomotor dan spiritual).

Pada hakikatnya tujuan pendidikan Islam adalah idealitas (cita-cita), yaitu idealitas yang mengandung nilai-nilai Islami yang mana itu semua dicapai dalam proses kependidikan yang berdasarkan ajaran Islam secara bertahap. Dalam hal ini Arifin menyampaikan, bahwa pendidikan Islam merupakan penggambaran nilai-nilai islami yang berhak diwujudkan dalam pribadi manusia didik pada akhir dari proses sebuah pendidikan. ${ }^{30}$

Tujuan pendidikan dalam Islam menurut Nawawi merupakan refleksi dari fungsi manusia sebagai ubudiyah dan khalifah. Pendidikan dalam prosesnya haruslah mengarah kepada pendekatan diri kepada Allah dan kesempurnaan insani, yaitu mengarahkan manusia untuk mencapai kebahagiaan dunia dan akhirat. Sebagaimana tercermin dari perkataannya tersebut, maka tujuan pendidikan dalam Islam (memperoleh ilmu) menurut Nawâwî itu ada empat, yakni: (a) Agar memperoleh ridho (kerelaan) dari Allah (mardatillab) dan memperoleh kebahagiaan hidup di akhirat, (b) Untuk menghilangkan kebodohan dari diri sendiri, orang lain (peserta didik), dengan cara setelah mendapat ilmu ia harus mengajar orang lain untuk menghilangkan kebodohan, (c) Menghidupkan agama dan mengabadikan Islam dengan sinaran ilmu, (d) Untuk mensyukuri nikmat Allah, berupa pemberian akal dan kesehatan badan. Sebaliknya jangan sampai tujuannya hanya untuk mendapatkan pujian dari orang banyak atau hanya untuk memperoleh keuntungan dunia semata, serta jangan pula hanya untuk mendapat kehormatan di mata penguasa. Kata syukur dalam konsep Nawâwî mencakup; segi kognitif/keilmuan (seseorang mengetahui nikmat yang di terimanya itu semata-mata berasal dari Allah), segi efektif (seseorang merasa gembira dan senang memperoleh ni'mat itu) dan segi psikomotorik dan spiritual (seseorang menggunakan ni'mat itu sesuai dengan ridha/kerelaan dari pemberi nikmat itu (Allah). ${ }^{31}$

Dari empat Tujuan pendidikan dalam Islam yang digagas Nawawi, yakni memperoleh ilmu untuk mencari ridho dari Allah dan mencapai persiapan kehidupan akhirat adalah merupakan realitas dari fungsi manusia untuk ubudiyah, sedangkan tujuan lainnya berkaitan dengan fungsi manusia sebagai khalifah. Maksud manusia untuk ubudiyah ialah semua aktivitas manusia harus dibingkai dengan nilai mardatillah dan kebahagiaan akhirat. Sedangkan fungsi manusia sebagai khalifah adalah bagaimana mengatur kehidupan dan mengolah alam semesta ini untuk kemakmuran bagi manusia sekarang dan generasi mendatang, sekaligus juga ubûdiyah.

\footnotetext{
${ }^{30}$ H. M. Arifin, Ilmu Pendidikan Islam: Suatu Tinjauan Teoritis dan Praktis Berdasarkan Pendekatan Interdisipliner (Jakarta: Bumi Aksara, 1991), 54.

${ }^{31}$ Muhammad Ridwan Hidayatulloh, Aceng Kosasih, dan Fahrudin Fahrudin, "Konsep Tasawuf Syaikh Nawawi Al-Bantani dan Implikasinya terhadap Pendidikan Agama Islam di Persekolahan," TARBAWY: Indonesian Journal of Islamic Education 2, no. 1 (5 Mei, 2015): 1-15, https://doi.org/10.17509/t.v2i1.3373.
}

Khazanah, Vol. 17 (2), 2019 


\section{Metode Pengajaran}

Menurut Nawawi upaya pendidik untuk memilih metode pengajaran yang tepat dalam mendidik peserta didik harus disesuaikan dengan tuntutan agama, yaitu seorang pendidik harus mengusahakan agar pelajaran yang diberikannya mudah diterima. Pendekatan ini tidak cukup dengan bersikap lemah lembut saja, akan tetapi pendidik harus pula memikirkan metode pengajaran yang cocok digunakan untuk peserta didik, seperti mimilih waktu yang tepat, materi yang cocok, pendekatan yang baik, efektivitas penggunaan metode dan sebagainya. Dia menggambarkan "ilmu syari'at itu dengan perahu, ilmu thariqah dengan laut, dan ilmu haqiqah dengan mutiara. Mutiara itu tidak bisa diperoleh kecuali di lautan dan peserta didik tidak bisa sampai di tengah laut tanpa menggunakan perahu. Haqīahnya ilmu itu seperti mutiara yang berada di tengah laut dan fungsi pendidik adalah menunjukkan jalan kepada peserta didik untuk meraih mutiara tersebut. Peserta didik tidak mungkin bisa meraih mutiara tersebut kecuali dengan menggunakan alat, yaitu perahu untuk mengantarkan peserta didik agar sampai ditengah laut. Karena mutiara itu berada didasar laut, maka peserta didik harus berani terjun dan menyelam kedasar laut. Kesemuanya itu tidak akan berhasil tanpa adanya persiapan mental, kesehatan jasmani/rakhani, sabar dan sungguh-sungguh untuk meraih mutiara tersebut. Ia juga mengatakan: Sebagian ulama' menggambarkan tiga perkara tersebut (syari'at, thariqah dan haqiqah) dengan buah kelapa. Syariat itu seperti kulit luar kelapa, thariqah seperti santan, dan haqiqah itu seperti minyak dalam santan. Minyak tidak dapat dihasilkan kecuali sesudah memeras santan dan santan tidak akan di temukan kecuali dengan membelah kulit kelapa. ${ }^{32}$

Dari dua gambaran tersebut dapat ditarik kesimpulan bahwa pada intinya metode itu berfungsi untuk mengantarkan peserta didik pada suatu tujuan kepada objek sasaran tersebut. Dalam al-Qur'an, metode dikenal sebagai sarana yang akan menyampaikan seseorang kepada tujuan penciptaannya sebagai khalifah dimuka bumi dengan melaksanakan pendekatan yang mana manusia ditempatkan sebagai makhluk yang memiliki potensi rohaniyah dan jasmaniyah, yang keduanya dapat digunakan sebagai saluran penyampaian materi pelajaran. Pendidikan merupakan pengenalan dan pengakuan mengenai tempat sesuatu sesuai dengan tatanan penciptaan yang ditanamkan secara progresif ke dalam diri manusia, menggiring pada pengenalan dan pengakuan Tuhan dalam tatanan wujud dan maujud. Pendidikan adalah proses ganda, bagian pertamanya melibatkan masuknya unit-unit makna (ma'na) suatu obyek pengetahuan ke dalam jiwa seseorang (bushû̉) dan yang kedua melibatkan sampainya jiwa (wusbul) pada unit-unit makna tersebut. Ini semua menunjukkan pengetahuan mengenai realitas individu: hakikat yang sesungguhnya, daya pikirnya, jiwa dan kecenderungan etikanya, juga peranan serta tanggung jawabnya di dunia dan tujuan akhirnya di akhirat. Di sini tampak sangat jelas dalam mata hati kita bahwa kebenaran metafisis sentralitas Tuhan sebagai realitas tertinggi sepenuhnya selaras dengan tujuan dan makna adab yaitu pendidikan sebagai ta'dib. Nawâwî sendiri dalam karyanya sering

\footnotetext{
${ }^{32}$ Suwarjin Suwarjin, "Biografi Intelektual Syekh Nawawi Al-Bantani," Tsaqofah dan Tarikb: Jurnal Kebudayaan dan Sejarah Islam 2, no. 2 (30 Desember, 2017): 189-202, https://doi.org/10.29300/ttjksi.v2i2.717. 
menggunakan kata adab; baik itu mengenai adab sholat, adab guru, adab murid, adab berteman, dan lain sebagainya.

Bertolak dari dasar pandangan Nawawi tersebut diatas, cara lain yang digunakannya dalam memberikan materi pendidikan adalah melalui metode pembiasaan yaitu melatih seseorang untuk melakukan sesuatu secara bertahap. Dalam hubungan ini terdapat petunjuk Nabi yang menyuruh orang tua agar membiasakan anaknya menunaikan shalat pada usia 7 tahun, selanjutnya membolehkan memukulnya jika anak itu sampai umur 10 tahun belum juga mengerjakan shalat. ${ }^{33}$ Dia berpendapat bahwa dalam proses pembelajaran, siswa akan mendemonstrasikan tingkat pemahaman terhadap makna pembelajaran itu. Hal ini karena ilmu dan hikmah yang merupakan dua komponen utama dalam konsep adab benar-benar merupakan anugerah Allah SWT.

\section{Kurikulum}

Konsep kurikulum yang disusun Nawawi sesuai dengan pandangannya mengenai tujuan pendidikan, yakni mendekatkan diri kepada Allah. Menurut Nawâwî, mendekatkan diri kepada Allah merupakan tolak ukur kesempurnaan manusia, dan untuk mencapai kesempurnaan ada jembatan yang disebut ilmu pengetahuan. Jika ilmunya banyak dan sempurna, ia akan semakin dekat kepada Allah dan semakin menyerupai malaikat. Disini Nawawi mengatakan; Babwa sebenamya bidayah (seorangyang berjalan, di jalan Allah SWT) itu adalah buah dari ilmu, dan di dalam bidayah itu ada bidayah dan nibayah. Bidayah itu juga dinamakan ilmu syari" ah dan thoriqob, sedangkan nibayah itu dinamakan ilmu baqiqah, karena sebenamya haqiqah-nya sesuatu itu merupakan akbir dari sesuatu tersebut. Adapun haqiqah yaitu buah dari pengamalan ilmu syari" ah dan thoriqoh secara bersamaan. Ia juga mengatakan; Sesungguhnya setiap batin itu ada dhobir-nya, dan sebaliknya. Syari'ah itu dhohir-nya haqiqah, dan haqiqah itu merupakan batin-nya syari"ah. Kedua-duanya saling berkaitan di dalam ma'nanya. Maka syari'ah tanpa haqiqah itu kosong (tidak berbuab). Dan haqiqah tanpa syari" ah itu batal (tidak ada kebaikannyal tidak berhasil). Semua manusia itu esensinya sama. Ia sudah kenal betul dengan pencipta, sehingga ia selalu ingin mendekat kepada-Nya, dan itu tidak akan berubah. Akan tetapi setelah esensi itu menyatu dengan fisik, ia akan berubah sehingga berbeda antara manusia yang satu dengan yang lainya. Berdasarkan kenyataan semacam inilah, menurutnya manusia adalah pribadi yang satu, yang tidak dapat dan atau tidak boleh disamakan denga pribadi yang lain. Tingkat pemahaman, daya tangkap, daya ingatnya terhadap ilmu pengetahuan, dan kemampuan menjalankan tugas hidupnya, berbeda antara orang yang satu dengan yang lain. Oleh karena itu dalam kaitannya dengan kurikulum, Nawawi mendasarkan pemikirannya bahwa kurikulum harus disusun dan selanjutnya disampaikan kepada murid sesuai dengan pertumbuhan dan perkembangan psikisnya.

\footnotetext{
${ }^{33}$ Nawawi al-Bantani, Mirqotu Shu'ud al-Tashdīq Fi Syari Sulam al-Taufiq (Kediri: Hidayah alTholab, n.d.), 18.
} 
Karena ilmu itu merupakan hidayah, dan hidayah tidak bisa masuk pada diri manusia yang hatinya masih kotor. ${ }^{34}$

Al-Qur'an al-Karim adalah kitab terbesar yang menjadi sumber pegangan pendidikan dan pengajaran bagi umat Islam. Sudah seharusnya kurikulum pendidikan Islam disusun sesuai dengan al-Qur'an al-Karim dan al-Hadits untuk melengkapinya. Banyak sinyal al-Qur'an tentang bentuk kurikulum pendidikan Islam. Di antaranya muatan materi yang mampu menyesuaikan perkembangan zaman, mampu memprediksi apa yang akan terjadi, sistematis, mudah dicerna dan dilaksanakan, serta muatanya menyentuh seluruh aspek kemanusiaan (jasmani, akal, dan al-qalb), dan lain sebagainya. Sesuai dengan tuntutan al-Qurean, inti kurikulum pendidikan Islam menurut Nawawi adalah tauhid; diwajibkan bagi kamu pertama kali adalah mengetabui Drat yang disembah kemudian menyembah-Nya. Bagaimana kamu bisa menyembah Drat yang tidak. kamu ketabui nama-nama-Nya, sifat-sifat dzat-Nya, sifat-sifat yang wajib dan mustabil bagi-Nya. Terkadang kamu meyakini tentang sesuatu yang mustabil dan yang bertentangan dengan kebenaran itu masuk dalam sifat-siafatnya Allah. Maka ibadahmu akan seperti debu-debu yang beterbangan. Untuk itu apabila kamu ingin beribadah kepada Allah, maka wajib bagi kamu pertama kali mengetahui bahwa Tuban kamu adalab Dzat yang maha mengetahui, maha kuasa, maha berkehendak....dst. Dalam konteks ini, tauhid berarti manusia lemah dan meyakini Allah sebagai satu-satunya Pencipta, Penguasa, Pemberi baginya diawal dan di akhir usahanya. Tauhid adalah suatu istilah untuk menyatakan kemahaesaan Allah atas semua makhluq-Nya. Allah merupakan esensi dan inti dari ajaran Islam dan merupakan nilai dasar dari realitas kebenaran yang universal untuk semua tempat dan waktu dari sejarah makhluk dan menjadi inti dari prinsip-prinsip dasar yang harus diikuti oleh manusia. Untuk itu, Nawawi memandang tauhid sebagai pandangan hidup umat Islam, yang meliputi konsep ketauhidan Allah, ketauhidan alam semesta, ketauhidan dalam hubungan Allah dengan kosmos, ketauhidan kehidupan, ketauhidan natural dan supra natural, ketauhidan pengetahuan, ketauhidan iman dan rasio, ketauhidan kebenaran, ketauhidan agama, ketauhidan cinta dan hukum, ketauhidan umat, ketauhidan kepribadian manusia, ketauhidan kebebasan, ketauhidan dalam kehidupan sosial, ketauhidan negara dan agama, ketauhidan dalam dasar satu cita satu ide. ${ }^{35}$

Kurikulum pendidikan Islam yang tidak didasarkan pada tauhid akan melahirkan manusia yang serba tergantung kepada makhluk, dan akan melahirkan manusia-manusia yang menyimpan tuhan-tuhan kecil selain Allah serta melahirkan musyrik-musyrik kecil pula. Dalam kurikulum pendidikan Islam, Syekh Nawawi menekankan ilmu muqaddimaat karena ilmu-ilmu keagamaan itu berbahasa Arab dan peserta didik berkewajiban mempelajarinya.

Pada masa sekarang ini bahasa sangat dipentingkan dalam kurikulum pendidikan Islam. Bahkan kelemahan-kelemahan sekolah-sekolah keagamaan sekarang ini ialah kelemahan penguasaan bahasa. Hal ini sependapat dengan pendapat tokoh

\footnotetext{
${ }^{34}$ Nawawi al-Bantani, Qami' al-Tughyan Ala Manzumah Sya'ab al-Iman (Kediri: Hidayah al-Tholab, n.d.), 7 dan 11.

${ }^{35}$ Yahya Zahid Ismail, "Konsep Pendidikan Nawawi Al-Bantani," Ulûmuna: Jurnal Studi Keislaman I, no. 2 (2015): 121-45.
} 
pendidikan Islam kontemporer, karena di samping menganggap penting pengetahuanpengetahuan yang diperoleh (acquired) melalui akal juga mementingkan pengetahuan melalui wahyu (perennia). Sebab wahyu, al-Qur'an dan Sunnah ini tertulis dalam bahasa Arab. Maka keahlian bahasa Arab, terutama yang berkenaan dengan tuntutan dasar Islam seperti ibadat sembahyang dan lain-lain haruslah dikuasai oleh murid-murid dari tingkat dasar. ${ }^{36}$

Peserta didik sebagai makhluk educandum dan educandus menurut Syekh Nawawi sangat memperhatikan lingkungan kebudayaan termasuk pendidikan dan sosialnya. Kehidupan peserta didik berada dalam suatu kontrak sosial. Eksistensi peserta didik berada dalam interdependensi baik secara sosial maupun lingkungan kebudayaan. Pengaruh lingkungan luar terhadap peserta didik sangat signifikan. Untuk itu Syekh Nawawi membuat etika peserta didik, agar lebih selektif dalam memilih lingkungan sosial dan teman dalam pergaulan. ${ }^{37}$ antaranya: $:^{38}$

Beberapa etika peserta didik terhadap ilmu menurut Syekh Nawawi di

a. Membersihkan hatinya dari kotoran-kotoran dan dosa untuk menerima ilmu, memeliharanya dan mendapatkan hasilnya.

b. Selalu mencari ridha gurunya sekalipun berbeda pendapat dengannya, tidak boleh mengumpat atau memfitnahnya, dan tidak boleh mencari-cari kesalahannya secara sembunyi-sembunyi.

c. Ia seharusnya tamak dalam belajar, disiplin dalam seluruh waktunya, malam, siang, berada di tempat dan waktu musyafir.

d. Bersabar atas perilaku guru dan kejahatan akhlaknya.

e. Memperhatikan kesahehan pelajaran yang ia dapatkan secara benar dan meyakinkan dari gurunya.

Adapun prinsip-prinsip metodik dalam pendidikan Islam menurut pendapat Syekh Nawawi, sebagai berikut: ${ }^{39}$

a. Menyajikan mata pelajaran secara jelas dimulai dari yang mudah, yang konkrit yang dapat ditangkap oleh akal pikiran peserta didik, baru kemudian secara bertahap dibawa kepada yang lebih sulit dan abstrak.

b. Dalam penyampaian materi, pendidik harus melihat keadaan peserta didiknya terutama dalam hal kemampuan dan tipologinya.

c. Menggunakan metode mengajar sesuai dengan keadaan peserta didiknya.

\footnotetext{
${ }^{36}$ Hasan Langgulung, Manusia dan Peradaban, Suatu Analisa Psikologi dan Pendidikan (Jakarta: alHusna Zikra, 1995), 203.

${ }^{37}$ Lili Hidayati, "Nashoihul 'Ibad Karya Syekh Nawawi Al-Bantani dan Pendidikan Kekinian," INSANLA: Jurnal Pemikiran Alternatif Kependidikan 20, no. 2 (June 15, 2015): 231-243, https://doi.org/10.24090/insania.v20i2.1436.

${ }^{38}$ Sutiyah Nova Irawati, "Etika Berilmu dalam Perspektif Nawawi Al-Bantani," EL-BANAT: Jurnal Pemikiran Dan Pendidikan Islam 8, no. 1 (19 November, 2018): 136-54. 2001), 233.

${ }^{39}$ Azyumardi Azra, Pendidikan Islam: Tradisi dan Modernisasi Menuju Milenium Baru (Kalimah,
}

Khazanah, Vol. 17 (2), 2019 
d. Guru dalam menyampaikan materi tidak menambah pelajaran sebelum pelajaran yang terdahulu dipahami peserta didiknya karena hal itu akan membuat peserta didik menjadi malas.

e. Prinsip pengulangan (tikrar) dalam pengajaran.

Selain itu, Syekh Nawawi juga mengemukakan bahwa etika relasi guru dan murid juga memberikan etika bersama antara guru dan murid. Yaitu keduanya tidak boleh melanggar kewajiban, fungsi dan kedudukan masing-masing pihak, seperti adanya penyakit ringan dan semisalnya yang dengannya ia bekerja atau sibuk. Dan ia meminta sembuh dengan ilmu dan tidak boleh bertanya kepada seseorang dengan cara menekan dan melemahkan. Bagi penanya yang demikian tidak berhak mendapatkan jawaban. ${ }^{40}$

Salah satu lembaga pendidikan yang penting ialah pendidikan keluarga. Keluarga memiliki dampak yang besar dalam pembentukan perilaku dan pengembangan vitalitas dan ketenangan dalam keluarga. Melalui keluarga, anak-anak mendapatkan bahasa, nilai dan norma serta kecenderungan mereka. ${ }^{41}$ Ulama-ulama Islam klasik menekankan pentingnya peranan pendidikan bagi keluarga dan pentingnya keluarga memegang peranan itu terutama pada usia kanak-kanak. Hal itu berdasar pengalaman-pengalaman mereka sendiri, juga pengalaman dan perhatian orang-orang sebelumnya. selain itu, nash-nash al-Qur'an, sunnah dan bekas-bekas peninggalan Assalaf-Saleh yang banyak menekankan pentingnya peranan pendidikan bagi keluarga. ${ }^{42}$

Syekh Nawawi menambahkan bahwa tanggung jawab pendidikan dalam keluarga tidak hanya mengirimkan anak kepada guru, tetapi juga tentang biaya pendidikannya. Apabila keluarga tidak mampu, maka biaya pendidikan dibebankan kepada pemerintah, sedangkan apabila pemerintah tidak mampu maka tanggung jawabnya dibebankan kepada orang-orang yang mampu. ${ }^{43}$

Posisi Syekh Nawawi dalam peta pemikiran pendidikan Islam lebih dekat kepada perenialis-enensialis madzhabi. Karena dari sisi parameternya, beliau dalam memperkuat uraian pemikiran pendidikan banyak mengemukakan nash, dan pemikiran salaf asshalih masa abad klasik dan pertengahan. Disamping itu, ia mempertahankan dan melestarikan pemikiran para pendahulunya yang dianggap relevan dengan situasi sekarang. Dikatakan 'relevan' karena menurut syekh Nawawi, hasil pemikiran itu selalu terbuka untuk dikritik bahkan ditinggalkan. Cciri-ciri pemikiran Nawawi, menekankan pada pemberian syarh dan hasyiyah terhadap pemikiran pendahulunya dan berani mengkritisi atau mengembangkan pemikiran pendahulunya untuk merekonstruksi

\footnotetext{
${ }^{40}$ Nury Firdausia, Pendidikan Moral dan Spiritual dalam Membangun Karakter Bangsa: Analisis Kitab Nashoibul 'Ibad Karya Syaikh Nawawi al-Bantani (Jakarta: Puslitbang Pendidikan Agama dan Keagamaan, Badan Litbang dan Diklat, Kementerian Agama RI, 2012), 120.

${ }^{41}$ Asep Nuhdi, "Pendidikan Anak Usia Dini dalam Perspektif Syekh Nawawi al-Bantani Kajian Kitab Uqud Al-Lujain ,Tanqih Al-Qaul dan Maraqi Al-Ubuddiyah," WALADUNA 1, no. 2 (2018): 2541.

${ }^{42}$ Langgulung, Manusia dan Peradaban, Suatu Analisa Psikologi dan Pendidikan.

${ }^{43}$ Nuhdi, "Pendidikan Anak Usia Dini dalam Perspektif Syekh Nawawi al-Bantani Kajian Kitab Uqud Al-Lujain ,Tanqih Al-Qaul dan Maraqi Al-Ubuddiyah.” 
pemikirannya sendiri. Gaya pemikiran Nawawi yang demikian itu telah, menempatkan beliau mempunyai kemampuan yang orisinial di bidang pendidikan Islam.

Dalam menggambarkan ide-ide dasar pendidikan, kecenderungan Syekh Nawawi terhadap nuansa agamisnya lebih dominan sehingga aspek lain menjadi kurang dominan. Penafsiran realitas berpangkal pada agama, maka pendidikan pun dijadikannya sebagai instrumen untuk mencapai tujuan-tujuan keagamaan

Pemikiran Syekh Nawawi tersebut tentu memiliki dampak positif dan dampak negatif edukatifnya. Dampak positifnya adalah rasa tanggung jawab yang sangat kuat telah menghujam pada pemikiran pendidikannya, dan mengukuhkan rasa tanggung jawab moral. Penghargaannya terhadap persoalan pendidikan Islam sangat tinggi, bahkan menilainya sebagai wujud tanggung jawab keagamaan yang sangat luhur. Tugas mengajar dan belajar tidak sekadar sebagai tugas-tugas profesi kerja dan tugas-tugas kemanusiaan tetapi lebih jauh dari itu yakni sebagai tuntutan kewajiban agama. Tanggung jawab dan kewajiban agama sebagai titik sentral baik dalam kontruksi tataran konsep maupun tataran aplikasi pendidikan. Atau dengan kata lain jika tuntutan tidak sejalan dengan tuntutan keagamaan, maka yang harus didahulukan ialah tuntutan keagamaan.

Adapun dampak negatif edukatifnya Syekh Nawawi menjadi term al-'ilm yang dalam nash bersifat mutlak, bersifat muqayyad (terbatas), hanya pada ilmu keagamaan, dan kecenderungan pencapaian spiritual yang lebih menonjol, dan mendorong pemikiran pendidikan Islam ke arah pengabaian urusan dunia dengan segala kemanfaatan dan amal usaha yang sebenarnya boleh dinikmati. Pendidikan Islam yang cenderung mengabaikan urusan dunia tersebut, maka ilmu-ilmu yang bersifat keduniaan dikuasai oleh non muslim dan menjadi lemahnya pelaksanakan amar makruf nabi munkar dalam reformasi dan transformasi sosial yang bermoral. Padahal penguasaan dunia merupakan sarana pendakian kebahagiaan di akhirat.

Ide-ide Syekh Nawawi tentang etika pendidik dan peserta didik dan etika bersama terdapat implikasi bahwa tokoh ini melihat peserta didik masih memerlukan tuntunan dan bimbingan. Peserta didik belum bisa lepas dari pendidik, ia tetap dalam bimbingan dan pengawasan pendidik. Peserta didik merupakan orang yang belum dewasa, namun memiliki potensi yang luar biasa. Untuk itu pendidik berperan besar untuk mengaktualisasikannya. ${ }^{44}$

Dari berbagai keterangan Syekh Nawawi tentang kurikulum pengajaran, terdapat implikasi bahwa memandang pengetahuan itu berdasarkan dari sudut pandang aplikatif dari norma-norma agama bukan dari sudut substansi ilmu tersebut. Dengan kata lain dasar atau hal yang esensial didahulukan kemudian disusul dengan materi lain. Mendahulukan matan kitab dari pada syarb dalam pendidikan. Mendahulukan kewajiban personal kemudian disusul dengan kewajiban komunal dan sunnah komunal. ${ }^{45}$

\footnotetext{
${ }^{44}$ Asyiqul Mujahadah, Anwar Sa'dullah, dan Lia Nur Atiqoh Bela Dina, "Nilai-Nilai Pendidikan Akhlak dalam Kitab Qomi’ Al-Thughyan,” Vicratina: Jurnal Pendidikan Islam 4, no. 3 (16 Juli, 2019): 93 103.

${ }^{45}$ Mujahadah, Sa'dullah, dan Dina, 93-103.

Khazanah, Vol. 17 (2), 2019 
Dalam penelitian Hasan Ko Nakata, berkesimpulan bahwa teologi Asya’irah mengakui keselamatan tiga kategori. Pertama adalah kategori orang-orang yang meskipun tidak bersentuhan dengan dakwah Islam, tetapi telah mengadopsi monotheisme dengan penilaian mereka sendiri. Kedua kategori orang-orang yang telah menjalani agama secara individu karena misi Islam belum menyentuh mereka. Ketiga adalah kategori orang yang telah menjalani hidup mereka sebagai atheis yang yakin tidak menolak Tuhan dalam situasi dakwah Islam belum menyentuh mereka. ${ }^{46}$

Peneliti melihat bahwa pemikiran Syekh Nawawi al-Bantani dalam pendidikan bisa di aktualisasikan dalam masyarakat Indonesia yang religious dan multicultural. Seperti, prinsip-prinsip pendidikan yang mengacu kepada taubid ilabiyyah dan reformasi sosial. Sifat dasar manusia dan proses perkembangannya ialah fitrah taubid-dualis-interaktif berpengaruh dalam proses pembelajaran.

Syekh Nawawi telah berhasil membangkitkan dan menyegarkan kembali ajaran agama dalam bidang teologi dan berhasil mengeliminir kecenderungan meluasnya konsep absolutisme Jabarîyah di Indonesia. Dengan konsep tawakkal billah. ${ }^{47}$ Dalam konteks Islam Jawa, teologi Asy'arîyah dalam kadar tertentu sebenarnya telah dapat menumbuhkan sikap merdekanya dari kekuatan setelah tawakkal kepada Allah. Melalui konsep penyerahan diri kepada Allah, umat Islam disadarkan bahwa tidak ada kekuatan lain kecuali kekuatan Allah.

Kekuatan Allah tidak terkalahkan oleh kekuatan kolonialis. Di sinilah letak peranan Nawawi dalam pensosialisasian teologi Asy'ariyah yang terbukti dapat menggugah para muridnya di Makkah yang terkumpul dalam Koloni Jawa. Di samping itu, Syekh Nawawi juga banyak memperkenalkan pengertian sifat-sifat Allah. Ia menekankan bahwa seorang Muslim harus mempercayai bahwa Allah memiliki sifatsifat yang dapat diketahui dari perbuatannya karena sifat Allah adalah perbuatan-Nya. Kemudian dalam konsep tauhid ini Syekh Nawawi al-Bantani berhasil mensyarah beberapa kitab tauhid atau menjelaskan beberapa kitab tauhid yang di karang oleh para ulama. Ini menjadi kontribusi besar karena memudahkan bagi setiap kalangan yang mempelajari ilmu tauhid tersebut.

Seperti kitab Tijan al-Darary syarah Matan al-Bajury. Kitab ini ditulis pada tahun $1301 \mathrm{H}$ dan diterbitkan oleh pustaka al-Alawiyah Semarang. Dalam kitab ini Saikh al-Bajuri menjelaskan bahwa wajib kepada semua orang mukalaf untuk mempelajari ilmu tauhid, penjelasan dari Syekh al-Bajuri ini belum cukup jelas bagi orang awam atau masyarakat yang baru mempelajarinya. Karena dari penjelasan Syekh al-Bajuri ini tidak dijelaskan mukalaf itu seperti apa. Lalu kemudian diperjelaslah oleh Syekh Nawawi, bahwa mukalaf yang dimaksud dalam kitab tersebut adalah menyeluruh baik laki-laki dan perempuan, walaupun orang yang bodoh, setiap abid dan pembantu

\footnotetext{
${ }^{46}$ Hassan Ko Nakata, "The Border of Salvation : The Salvation of Non-Muslims in Islam," Journal of the Interdisciplinary Study of Monotheistic Religions: JISMOR 2 (2006), https://ci.nii.ac.jp/naid/110006608287/.

${ }^{47}$ Youpi Rahmat Taher, "Konsep Tauhid menurut Syaikh Nawai al-Bantani," Jurnal Aqidah Dan Filsafat Islam 2, no. 1 (2017): 60-73. 
mangka wajib bangsa A'in yaitu wajib yang dilakukan secara perorangan untuk mempelajari ilmu tauhid. ${ }^{48}$

Kitab Tijan Al-Darary ini merupakan kitab syarah (penjelasan) dari risalah alBajuri fi at-Tauhid yang ditulis oleh Syekh Bajuri sehingga kitab ini dinamai dengan Tijan al-Darary fi Syabri Risalah al-Bajuri dengan bahasa Arab. Kitab ini berisi tentang ilmu ketauhidan yang akan menuntun kita untuk lebih mengenal Allah SWT lewat sifatsifat-Nya. Kitab ini juga menjelaskan tentang sifat-sifat wajib dan jaiz bagi Allah SWT dan rasul-Nya serta nasab Rasulullah SAW.

Di samping itu, kitab ini juga menjadi dasar pembelajaran tauhid diberbagai pondok pesantren di seluruh Indonesia. Syekh Nawawi menekankan seorang Muslim harus mempercayai bahwa Allah memiliki sifat-sifat yang dapat diketahui dari perbuatannya karena sifat Allah adalah perbuatan-Nya dan memperkenalkan pengertian sifat-sifat Allah. Oleh karena itu sangatlah jelas bahwa Syekh Nawawi alBantani ini berkontribusi besar terhadap konsep tauhid karena pada dasarnya beliau telah mampu memudahkan setiap kalangan yang belajar mengenai ilmu tauhid dengan cara mengarang sebuah kitab atau mensyarah sebuah kitab tentang tauhid sehingga setiap kalangan yang mempelajari ilmu tauhid tersebut mudah memahaminya.

\section{Simpulan}

Syekh Nawawi al-Bantani adalah seorang ulama dan intelektual yang legendaris. Melalui karya-karyanya yang mendunia dalam berbagai bidang, menjadikannya panutan oleh banyak pemburu ilmu pengetahuan. Selain ilmu-ilmu agama, beliau juga ahli dalam bidang pendidikan. Karya-karyanya sangat luar biasa, karena banyak memiliki kandungan syarb yang padat tentang karya-karya ulama terdahulu dan telah di modifikasi sehingga memudahkan pembacanya. Pemikiran pendidikannya sangat komulatif dari mulai ide dasar, nilai-nilai, sampai panduan aktivitas pembelajaran dalam Islam. Dasarnya adalah kajiannya dari para pemikir klasik, pertengahan dan modern yang kemudian di integrasikan dengan buah pemikirannya sendiri. Menjadikan hasil dari pemikirannya sangatlah realitas dan dapat memenuhi kebutuhan para praktisi pendidikan Islam. Ditambah dengan pondasi pengetahuan keagamaan serta pemahaman hukum-hukum Islam yang mendalam, serta pengaruh para guru sehingga membentuk karakter yang matang. Sumber pemikiran pendidikan Islam tidak hanya dengan al-Qur'an dan as-Sunnah, Nawawi menambahkan Ijma', Qiyas, Ijtihad serta pendapat para ahli salaf as-shalih sebagai sumber pendidikan dalam Islam. Tujuan pendidikan dalam Islam merupakan sebuah refleksi dari fungsi manusia untuk beribadah kepada Allah yaitu dengan menjadi keridhoanNya, berjihad untuk memberantas kebodohan, berjihad untuk mengabadikan Islam dengan sinaran ilmu. Untuk pemikirannya tentang pendidik dan peserta didik, Nawawi mengungkapkan bahwa faktor kepribadian pendidik lebih penting daripada faktor yang lain, sedangkan dengan peserta didik sendiri hendaklah selalu berpegang teguh pada akhlak mulia dalam menghadapi guru, baik dalam proses belajar mengajar ataupun dalam berinteraksi dengan guru dalam kehidupan sehari-hari.

${ }^{48}$ Taher, 60-73.

Khazanah, Vol. 17 (2), 2019 


\section{Daftar Pustaka}

Arifin, H. M. Ilmu Pendidikan Islam: Suatu Tinjauan Teoritis dan Praktis Berdasarkan Pendekatan Interdisipliner. Bumi Aksara, 1991.

Azra, Azyumardi. Pendidikan Islam: Tradisi dan Modernisasi Menuju Milenium Baru. Kalimah, 2001.

Bantani, Nawawi al-. Mirqotu Shu'ud al-Tashdiq fi Syari Sulam al-Taufiq. Kediri: Hidayah al-Tholab, n.d.

- Qami' al-Tughyan Ala Manzumah Sya'ab al-Iman. Kediri: Hidayah al-Tholab, n.d.

Bashori -. "Pemikiran Pendidikan Syekh Nawawi Al-Bantani." Hikmah: Jurnal Pendidikan Islam 6, no. 1 (1 Juni, 2017): 37-58.

Burhanuddin, Mamat S. Hermeneutika Al-Qur'an ala Pesantren: Analisis terhadap Tafsir Marāh Labid Karya K.H. Nawawi Banten. UII Press, 2006.

Fahmi, Muhammad Ulul. Ulama Besar Indonesia: Biografi dan Karyanya: Syekh Nawawi alBantani, Syekh Kholil Bangkalan, Syekh Mahfudh at-Turmusi, Syekh Yasin Padang, Syekh Ihsan Jampes, Syekh Muslih Mranggen, dan Lainnya. Yogyakarta: Kerja sama Pondok Pesantren Al-Itqon dengan Pustaka Amanah Kendal, 2008.

Faiqoh, Nurul. "Pemikiran Pendidikan Islam Syekh Nawawi Al-Bantani Dan Implikasinya Terhadap Pendidikan Modern." At-Tajdid: Jurnal Ilmu Tarbiyah 4, no. 1 (1 Januari, 2015): 1-12.

Firdausia, Nury. Pendidikan Moral dan Spiritual dalam Membangun Karakter Bangsa: Analisis Kitab Nashoibul 'Ibad Karya Syaikh Nawawi al-Bantani. Puslitbang Pendidikan Agama dan Keagamaan, Badan Litbang dan Diklat, Kementerian Agama RI, 2012.

Hamid, Shalahuddin, and Iskandar Ahza. Seratus Tokoh Islam yang Paling Berpengaruh di Indonesia. Intimedia, 2003.

Hidayati, Lili. "Nashoihul 'Ibad Karya Syekh Nawawi Al-Bantani dan Pendidikan Kekinian." INSANIA : Jurnal Pemikiran Alternatif Kependidikan 20, no. 2 (15 Juni, 2015): 231-43. https://doi.org/10.24090/insania.v20i2.1436.

Hidayatulloh, Muhammad Ridwan, Aceng Kosasih, dan Fahrudin Fahrudin. "Konsep Tasawuf Syaikh Nawawi Al-Bantani dan Implikasinya terhadap Pendidikan Agama Islam di Persekolahan." TARBAWY: Indonesian Journal of Islamic Education 2, no. 1 (5 Mei, 2015): 1-15. https://doi.org/10.17509/t.v2i1.3373.

Hurgronje, Snouck. Mekeka in the Latter Part of the 19th Century: Daily Life, Customs and Learning. The Moslims of the East-Indian Archipelago. Leiden: BRILL, 2006. 
Ilyas, M. Azizzullah. "Ajaran Syeikh Nawawi al-Bantani tentang Pendidikan Akhlak Anak." AR-RLAYAH: Jurnal Pendidikan Dasar 2, no. 2 (22 Januari, 2019): 11326. https://doi.org/10.29240/jpd.v2i2.659.

Irawati, Sutiyah Nova. "Etika Berilmu dalam Perspektif Nawawi al-Bantani." ELBANAT: Jurnal Pemikiran Dan Pendidikan Islam 8, no. 1 (19 November, 2018): 136-54.

Iskandar, Salman. 55 Tokoh Muslim Indonesia Paling Berpengarub. Tinta Medina, 2011.

Ismail, Yahya Zahid. "Konsep Pendidikan Nawawi Al-Bantani." Ulumuna: Jurnal Studi Keislaman I, no. 2 (2015): 121-45.

Langgulung, Hasan. Manusia dan Peradaban, Suatu Analisa Psikologi dan Pendidikan. Jakarta: al-Husna Zikra, 1995.

Machasin. Islam Teologi Aplikatif. Pustaka Alief, 2003.

Maftuh, Rofik. "Inklusifitas Pemikiran Syaikh Nawawi al-Bantani." MAGHZA: Jurnal Ilmu Al-Qur'an Dan Tafsir 3, no. 1 (28 Juni, 2018): 119-33. https://doi.org/10.24090/maghza.v3i1.1960.

Maragustam, -. "Pemikiran Syaikh Nawawi al-Banjari tentang Manusia dan Implikasi dalam Pendidikan Islam.” Jurnal Kependidikan Islam I, no. 1 (1 Juli, 2003): 1-15.

Mas'ud, Abdurrahman. Dari Haramaian ke Nusantara; Jejak Intelektual dan Arsitek Pesantren. Jakarta: Kencana, 2006.

Masyhuri, Abdul Aziz, dan Zainal Arifin Thoha. 99 Kiai Kharismatik Indonesia: Riwayat, Perjuangan, dan Doa. Kutub, 2008.

M.Pd.I, Dr Hj Mihmidaty Ya'cub. Model Pendidikan Tasawnf pada Tariqah Shadhiliyah. Pustaka Media, 2018.

Mujahadah, Asyiqul, Anwar Sa'dullah, dan Lia Nur Atiqoh Bela Dina. "Nilai-Nilai Pendidikan Akhlak dalam Kitab Qomi' Al-Thughyan." Vicratina: Jurnal Pendidikan Islam 4, no. 3 (16 Juli, 2019): 93-103.

Nakata, Hassan Ko. "The Border of Salvation: The Salvation of Non-Muslims in Islam." Journal of the Interdisciplinary Study of Monotheistic Religions: JISMOR 2 (2006). https://ci.nii.ac.jp/naid/110006608287/.

Nata, H. Abuddin. Pembaruan Pendidikan Islam di Indonesia. Prenada Media, 2019.

Nuhdi, Asep. "Pendidikan Anak Usia Dini dalam Perspektif Syekh Nawawi AlBantani Kajian Kitab Uqud Al-Lujain,Tanqih Al-Qaul dan Maraqi AlUbuddiyyah." WALADUNA 1, no. 2 (2018): 25-41.

Pransiska, Toni. "Pendidikan Islam Transformatif Syaikh Nawawi Al-Bantani: Upaya Mewujudkan Generasi Religius-Saintifik." JURNAL ILMLAH DID AKTIKA: Media Ilmiah Pendidikan Dan Pengajaran 18, no. 2 (1 Februari, 2018): 172-88. https://doi.org/10.22373/jid.v18i2.3241. 
Ahmad Wahyu Hidayat \& Muhammad Iqbal Fasa

Sukmadinata, Nana Syaodih. Metode Penelitian Pendidikan. Bandung: Program Pascasarjana Universitas Pendidikan Indonesia dengan PT Remaja Rosdakarya, 2005.

Suwarjin, Suwarjin. "Biografi Intelektual." Tsaqofah dan Tarikb: Jurnal Kebudayaan dan Sejarah Islam 2, no. 2 (30 Desember, 2017): 189-202. https://doi.org/10.29300/ttjksi.v2i2.717.

Suwito, and Fauzan. Sejarah Pemikiran para Tokoh Pendidikan. Bandung: Angkasa Bandung, 2003.

Taher, Youpi Rahmat. "Konsep Tauhid Menurut Syaikh Nawawi Al-Bantani.” Jurnal Aqidah dan Filsafat Islam 2, no. 1 (2017): 60-73.

Tebba, Sudirman. Mengenalkan Wajab Islam yang Ramab: Sufi-Sufi Jawa. Pustaka Irvan, 2007. 